\title{
Single Nucleotide Polymorphism (SNP) IL-10 (RS 1800896) pada Infeksi Bakteri Gram negatif dan TLR-2 (RS 3804099) Infeksi Bakteri Gram positif Pada Sepsis Neonatorum
}

\author{
Lia Kamelia, Sjarif Hidajat Effendi, Dzulfikar DLH \\ Departemen Ilmu Kesehatan Anak Fakultas Kedokteran Universitas Padjadjaran/ Rumah Sakit Hasan Sadikin, Bandung
}

\begin{abstract}
Latar belakang. Sepsis neonatorum merupakan masalah kesehatan dengan tingkat morbiditas dan mortalitas yang tinggi. Kultur darah sebagai gold standar diagnostic hanya memberikan hasil positif sekitar 40\%. Latar belakang genetik saat ini diakui berkontribusi terhadap respons imunologis inang

Tujuan. Menentukan hubungan SNP IL-10 (rs 1800896) dengan infeksi bakteri Gram negatif dan TLR-2 (rs 3804099) dengan infeksi bakteri Gram positif pada sepsis neonatorum.

Metode. Penelitian rancangan cross sectional pada sepsis neonatorum. Subjek dengan hasil kultur darah positif dilakukan analisis genetik single nucleotide polymorphisms IL-10 (rs1800896) dan TLR-2 (rs3804099), dengan tahapan isolasi deoxyribonucleat acid (DNA), polymerase chain reaction (PCR), dan sekuensing DNA.

Hasil. Tidak didapatkan hasil yang bermakna (p>0,05) SNP IL-10 (rs1800896) dengan infeksi bakteri Gram negatifdan SNP TLR-2 (rs3804099) dengan infeksi bakteri Gram positif

Kesimpulan. Tidak terdapat hubungan single nucleotide polymorphism (snp) IL-10 (rs 1800896) dengan infeksi bakteri Gram negatifdan TLR-2 (rs 3804099) dengan infeksi bakteri Gram positif pada sepsis neonatorm. Sari Pediatri 2016;17(6):423-7.
\end{abstract}

Kata kunci: sepsis neonatorum, single nucleotide polymorphisms, interleukin-10, toll like receptor-2

\section{Single Nucleotide Polymorphisms Interleukin-10 (Registered/rs Snip 1800896) with Gram-Negative Bacterial Infections and Toll like receptor-2 (Register Snip 3804099) with Gram Positive Bacterial Infections in Neonatal Sepsis Patients}

Lia Kamelia, Sjarif Hidajat Effendi, Dzulfikar DLH

Background. Neonatal sepsis is a health problem with high morbidity and mortality. Blood culture as the gold standard diagnostic test provides only $40 \%$ positive results. Genetic background is recently recognized contributing factor to the host immunological response.

Objective. To determine the relationship between SNP IL-10 (rs 1800896) with gram-negative bacterial infections and TLR-2 with gram-positive bacterial infection.

Methods. This study is a cross-sectional categorical analytical study in neonatal sepsis. Samples with positive blood culture results underwent a genetic analysis of SNP of IL-10 (rs1800896) and TLR-2 (rs3804099) using deoxyribonucleic acid (DNA) isolation, polymerase chain reaction (PCR), and DNA sequencing methods.

Results. There were no significant differences ( $\mathrm{p}>0.05)$ between the SNP-IL-10 (rs1800896) with gram-negative bacterial infections and SNP TLR-2 (rs3804099) with gram-positive bacterial infections.

Conclusion. Single nucleotide polymorphism IL-10 (rs 1800896) and TLR-2 (rs 3804099) have no relationships with gram-negative and gram positive bacterial infections in neonatal sepsis cases. Sari Pediatri 2016;17(6):423-7.

Keywords: neonatal sepsis, single nucleotide polymorphisms, interleukin-10, toll like receptor-2

\footnotetext{
Alamat korespondensi: Dr. Lia Kamelia. Departemen Ilmu Kesehatan Anak Fakultas Kedokteran Universitas Padjadjaran/Rumah Sakit Dr. Hasan Sadikin. Jl. Pasteur No. 38 Bandung 40163, Tel. +62 22-3035957. E-mail: lia_kamelia8066@yahoo.com
} 
S epsis neonatorum merupakan salah satu masalah kesehatan dengan tingkat morbiditas dan mortalitas yang tinggi, serta merupakan penyumbang utama (15\%) mortalitas pada bayi. Di negara berkembang, angka kejadiannya masih cukup tinggi 1,8-18/1000 kelahiran hidup, di Rumah Sakit Hasan Sadikin Bandung, kejadian sepsis neonatorum selama tahun 2010-2013 sebesar 1415 kasus. World Health Organization (WHO) melaporkan 5 juta kematian neonatus setiap tahun dengan angka mortalitas 34/1000 kelahiran hidup di Asia. ${ }^{1-4}$

Beberapa bakteri yang sering menjadi etiologi sepsis neonatorum adalah bakteri Gram negatif (Escherichia coli, Pseudomonas sp, Serratia sp, Acinetobacter sp, Proteus mirabilis) dan Gram positif (Coagulase negative Staphylococcus, Enterococcus, Beta-haemolytic Streptococcus, Alpha-haemolytic Streptococcus). Berdasarkan waktu terjadinya mikroorganisme patogen yang sering berhubungan dengan early onset sepsis (EOS) adalah Escherichia coli dan bakteri yang berhubungan dengan late onset sepsis (LOS) adalah Klebsiella. ${ }^{5-7}$

Bukti terbaru melaporkan bahwa latar belakang genetik memengaruhi respons imunologis terhadap infeksi, sedangkan identifikasi penanda genom berguna untuk memahami variasi regulasi dan ekspresi protein pada sistem imunologis. Polimorfisme beberapa gen diketahui memengaruhi respons imun dan kerentanan terhadap sepsis. Interleukin-10 ( IL-10) dan Toll like receptor-2 (TLR-2) merupakan komponen yang diketahui berperan penting terhadap respons inflamasi dan respons imun saat terjadinya infeksi Gram positifdan gram negatif. Penelitian di Pensylvania menunjukkan hubungan bermakna variabel single nucleotide polymorphisms inter leukin-10 (SNP IL10) (rs1800896) dan TLR-2 (rs3804099) dengan infeksi bakteri Gram positifdan gram negatif; penelitian dilakukan secara whole genomic yang meliputi berbagai komponen yang terlibat dalam sistem imunitas tubuh manusia. Di RSUP Dr. Hasan Sadikin Bandung sampai saat ini belum ada penelitian yang menggali kemungkinan peranan variasi genetik tubuh inang terhadap respons imun bayi sepsis neonatorum. Penelitian ini menilai SNP IL-10 (rs1800896) infeksi bakteri Gram negatifdan TLR-2 (3804099) infeksi bakteri Gram positif pada penderita sepsis neonatorum. ${ }^{8,9}$

\section{Metode}

Subjek penelitian adalah neonatus sepsis dengan kriteria inklusi usia 0-28 hari yang memenuhi kriteria sepsis menggunakan skor Tollner, neonatus yang lahir di dalam atau di luar RSHS dan berobat serta dirawat di Rumah Sakit Umum Pusat (RSUP) Dr. Hasan Sadikin Bandung; sedangkan kriteria eksklusi meliputi kelainan kongenital dan penyakit autoimun pada neonatus.

Bayi sepsis atau suspek sepsis yang dirawat di RSUP Dr. Hasan Sadikin Bandung periode Januari 2015 sampai dengan Juni 2015 dilakukan pemeriksaan kultur darah dan apabila hasil kultur darah positif dilakukan pemeriksaan SNP IL-10 (rs1800896) dan TLR-2 (rs3804099), kemudian dilakukan perbandingan antara hasil SNP gen IL-10 (rs1800896) dan TLR-2 (rs3804099) dengan hasil kultur bakteri penderita sepsis neonatorum. Penelitian ini telah mendapat persetujuan dari Komite Etik Penelitian Fakultas Kedokteran Universitas Padjadjaran/ RSUP Dr. Hasan Sadikin, Bandung.

\section{Hasil}

Terdapat 67 bayi dengan diagnosis sepsis (berdasarkan kriteria skor Tollner), 40 bayi dengan hasil kultur darah positif, terdiri atas 15 bayi dengan hasil kultur bakteri Gram positif dan 25 bayi dengan hasil kultur bakteri Gram negatif.

Tabel 1. Karakteristik umum subjek penelitian $(\mathrm{n}=40)$

\begin{tabular}{lc}
\hline Variabel & Jumlah \\
\hline Jenis kelamin & \\
$\quad$ Laki-laki & 26 \\
$\quad$ Perempuan & 14 \\
Berat badan (gram) & \\
$\quad<2000$ & 18 \\
$2000-<2500$ & 9 \\
$\geq 2500$ & 13 \\
Cara persalinan & \\
$\quad$ Spontan & 26 \\
$\quad$ Sectio Caesaria & 14 \\
Onset & \\
$\quad$ Awitan dini & 31 \\
$\quad$ Awitan lanjut & 9 \\
Tempat persalinan & \\
$\quad$ Rumah sakit & \\
Luar rumah sakit & 24 \\
\end{tabular}


Karakteristik umum subjek penelitian terdiri atas jenis kelamin, berat badan, cara persalinan, onset, tempat persalinan, serta jenis sepsis early dan late onset sepsis tertera pada Tabel 1.

Pada tabel 1, bayi laki-laki, persalinan spontan, dan sepsis awitan dini lebih sering terjadi pada sepsis neonatorum. Ditemukan berbagai jenis bakteri Gram positifdan Gram negatif, bakteri terbanyak adalah kelompok Gram negatif, berikut jenis-jenis bakteri yang ditemukan pada pemeriksaan kultur darah 40 subjek penelitian (Tabel 2).

Alel IL-10 (rs1800896) diperiksa pada infeksi bakteri Gram positifdan Gram negatif sepsis neonatorum tertera pada Tabel 3.

Alel A dan alel G pada IL-10 (rs1800896) tidak berhubungan bermakna dengan hasil kultur infeksi

Tabel 2. Jenis-jenis bakteri pada pemeriksaan kultur darah $(\mathrm{n}=40)$

\begin{tabular}{lcc}
\hline Jenis bakteri & $\begin{array}{c}\text { Gram Positif/ } \\
\text { Negatif }\end{array}$ & $\begin{array}{c}\text { Jumlah } \\
\text { subjek }\end{array}$ \\
\hline Klebsiella pneumoniae & Negatif & 10 \\
Acinetobacter baumani & Negatif & 4 \\
Burkholdesia cepacia & Negatif & 3 \\
E. coli & Negatif & 3 \\
Enterobacter cloacae & Negatif & 1 \\
Pseudomonas aeroginosa & Negatif & 1 \\
Aeromonas hydrophila & Negatif & 1 \\
Klebsiella ozaenae & Negatif & 1 \\
Stenotrophomonas maltrophilia & Negatif & 1 \\
Staphylococcus aureus & Positif & 6 \\
Staphylococcus haemoliticus & Positif & 3 \\
Staphylococcus epidermidis & Positif & 2 \\
Staphylococcus hominis & Positif & 2 \\
Staphylococcus warneri & Positif & 1 \\
Micrococcus & Positif & 1 \\
\hline
\end{tabular}

Tabel 3. Hubungan Alel IL-10 (rs1800896) dengan infeksi bakteri Gram positif dan Gram negatif

\begin{tabular}{lccc}
\hline Kelompok & Alel A & Alel G & Nilai-p* \\
\hline Bakteri Gram positif & & & \\
IL-10 (rs1800896) & 17 & 13 &
\end{tabular}

Bakteri Gram negatif

$\begin{array}{lll}\mathrm{IL}-10(\mathrm{rs} 1800896) & 21 & 29\end{array}$

Keterangan: A : Adenosin, G ; Guanin, IL ; interleukin * : Uji chi-quadrat bakteri Gram positif dan Gram negatif. Alel TLR-2 (rs3804099) juga diperiksakan pada infeksi bakteri Gram positif dan Gram negatif pada sepsis neonatorum tertera pada Tabel 4.

Alel T dan alel C pada TLR-2 (rs3804099) tidak berhubungan bermakna dengan hasil kultur infeksi bakteri Gram positif dan Gram negatif. Genotip TLR-2 (rs3804099) dan IL-10 (rs1800896) pada infeksi bakteri Gram positif dan bakteri Gram negative dihubungkan dengan dengan fenotip skor Tollner tertera pada Tabel 5 .

Tabel 4. Hubungan Alel TLR-2 (rs3804099) dengan infeksi bakteri Gram positif dan Gram negatif

\begin{tabular}{lccc}
\hline Kelompok & Alel T & Alel C & Nilai-p* \\
\hline Bakteri Gram positif & & & \\
TLR-2 (rs3804099) & 20 & 10 & 0,182 \\
& & & \\
Bakteri Gram negatif & & & \\
TLR-2 (rs3804099) & 40 & 10 & \\
\hline
\end{tabular}

Keterangan: T: Troponin, C : Cytosin * Uji chi-quadrat

Tabel 5. Hubungan genotip TLR-2 (rs3804099) dan IL-10 (rs1800896) dengan fenotip Skor Tollner

\begin{tabular}{llll}
\hline Kelompok (Alel) & $\begin{array}{l}\text { Individu } \\
\text { (jumlah) }\end{array}$ & \multicolumn{2}{c}{ Skor Tollner } \\
\cline { 3 - 4 } Bakteri Gram positif & & & $>10(\mathrm{n})$ \\
TLR-2 (rs3804099) & & 5 & 1 \\
TT & 6 & 3 & 5 \\
CT & 8 & 0 & 1 \\
CC & 1 & & \\
IL-10 (rs1800896) & & 3 & 2 \\
AA & 5 & 2 & 5 \\
AG & 7 & 3 & 0 \\
GG & 3 & & \\
Bakteri Gram negatif & & & \\
TLR-2 (rs3804099) & & 6 & 10 \\
TT & 16 & 6 & 2 \\
CT & 8 & 0 & 1 \\
CC & 1 & & \\
IL-10 (rs1800896) & & 2 & 1 \\
AA & 3 & 3 & 4 \\
AG & 15 & 7 & 7 \\
GG & & & \\
\hline
\end{tabular}

Keterangan : A : Adenosin, G : Guanin, C : Cytosin, T : Tiamin, IL : Interleukin, TLR : Toll like receptor 
Pada TLR-2 alel CC (polimorfisme) menunjukkan skor Tollner $>10$, baik pada kelompok bakteri Gram positif maupun Gram negatif. Pada IL-10 alel GG (polimorfisme) tidak menunjukkan perbedaan pada kelompok bakteri Gram positif.

\section{Pembahasan}

Pada awalnya terjaring 67 subjek dengan diagnosis sepsis menggunakan kriteria skor Tollner, terdapat 40 subjek dengan hasil kultur bakteri positif, berupa bakteri Gram positif 15 subjek dan Gram negatif 25 subjek. Bakteri yang paling banyak ditemukan adalah Klebsiella pneumoniae dan Staphylococcus aureus. Hal tersebut sesuai dengan beberapa penelitian yang melaporkan terjadi outbreak sepsis yang diakibatkan oleh Staphylococcus aureus pada bayi prematur critically ill dan merupakan bakteri utama yang bertanggung jawab terhadap kejadian sepsis neonatorum terbanyak di rumah sakit. ${ }^{10}$

Angka kejadian sepsis neonatorum lebih banyak pada bayi laki-laki. Hal tersebut sesuai teori yang menyatakan bahwa kromosom-X berperan penting dalam sistem imunitas tubuh, biasanya terjadi pada laki-laki yang hanya memiliki satu salinan kromosom-X. Bayi dengan berat badan lahir rendah sering mengalami sepsis neonatorum. Hal tersebut sesuai dengan hasil penelitian kami. Defisiensi imunologis pada bayi dengan berat lahir rendah terjadi akibat penurunan imunitas innate dan adaptive yang ditandai dengan penurunan produksi monosit dan neutrofil, penurunan kemampuan sel dalam mengatasi patogen, serta penurunan produksi sitokin yang mengurangi aktifasi sel $T^{11-13}$

Kami mendapatkan hubungan yang tidak bermakna SNP IL-10 (rs1800896) dan TLR-2 (rs3804099) dengan kultur bakteri Gram negative dan Gram positif, begitupun hubungan IL-10 alel A dan G dengan hasil kultur bakteri Gram negative dan positif. Hubungan TLR-2 alel T dan C dengan hasil kultur bakteri Gram positif dan negatif juga menunjukkan perbedaan yang tidak bermakna.

Pada infeksi bakteri Gram positif, berdasarkan genotip TLR-2 alel CC (polimorfisme homozigot), terdapat satu sampel penelitian dengan fenotip klinis severe sepsis, sedangkan pada genotip IL-10 alel GG (polimorfisme homozigot), tidak terdapat sampel penelitian yang mengalami severe sepsis. Hal tersebut sesuai dengan teori bahwa polimorfisme pada TLR-2 bertanggung jawab terhadap infeksi bakteri Gram positif. Pada alel polimorfisme heterozigot, baik alel CT genotif TLR-2 maupun alel AG genotif IL-10, terdapat lima sampel yang mengalami severe sepsis. Hal tersebut kemungkinan terdapat faktor lain yang memengaruhi, misalnya sistem imunitas atau virulensi bakteri yang menginfeksi. Peran alel sangat kecil dalam menentukan tingkat keparahan penyakit dan bukan kausa yang utama, diperlukan penelitian yang lebih lanjut mengenai peran polimorfisme alel pada pasien sepsis neonatorum.

Pada infeksi bakteri Gram negatif, genotip IL-10 alel GG (polimorfisme homozigot) terdapat empat sampel yang mengalami severe sepsis. Hal tersebut sesuai dengan teori bahwa polimorfisme IL-10 bertanggung jawab terhadap infeksi bakteri Gram negatif, sedangkan pada genotip TLR-2 terdapat satu sampel yang mengalami severe sepsis. Hal tersebut kemungkinan berkaitan dengan teori differential role of TLR-2 terhadap rekognisi Gram negatif akibat pengaktifan NF-kB oleh TLR-2 yang berespons terhadap lipopolysacaride (LPS) bakteri Gram negatif. Kemungkinan terjadi interaksi TLR-2 dengan CD-14 dari reseptor kompleks LPS.

Beberapa penelitian menemukan hubungan yang bermakna antara polimorfisme genetik dan kerentanan terhadap kejadian sepsis neonatorum. Hal tersebut karena polimorfisme akan mengatur dan mengode sejumlah protein yang terlibat pada rekognisi bakteri patogen yang menimbulkan variabilitas dalam merespon infeksi bakteri patogen. Sebaliknya, penelitian lain yang menginvestigasi hubungan tersebut melaporkan hasil yang kurang bermakna. Hal tersebut menunjukkan polimorfisme SNP dianggap berkontribusi lemah dan lebih menekankan konsep sepsis-induced immunoparalysis sehingga teori mengenai hal tersebut masih menjadi perdebatan. Walaupun demikian, kombinasi polimorfisme SNP individu dan faktor klinis memungkinkan peningkatan abilitas keparahan sepsis. ${ }^{14}$

Penelitian kami memiliki keterbatasan, dari 67 subjek yang didiagnosis sepsis neonatorum hanya 40 subjek yang mempunyai hasil kultur darah positif sehingga menyebabkan jumlah sampel yang sedikit.

\section{Kesimpulan}

Hasil penelitian menunjukkan bahwa tidak terdapat hubungan polimorfisme gen IL-10 (rs 1800896) 
dengan infeksi bakteri Gram negative dan gen TLR2 (rs3804099) dengan infeksi bakteri Gram positif. Genotip polimorfisme tidak menggambarkan fenotip tingkat keparahan pasien sepsis neonatorum.

\section{Daftar pustaka}

1. Shirazi H, Riaz S, Tahir R. Role of the hematological profile in early diagnosis of neonatal sepsis. Pakistan. Ann Pak Inst Med Sci 2010;6:152-6.

2. Damstadt G, Bhutta Z, Cousens S, Adam T, Walker N, Bernis L. Evidence based, cost effective interventions: How many newborn babies can we safe?. Lancet 2005;365:377-88.

3. Gerdes JS. Diagnosis and management of bacterial infection in the neonate. Pediatr Clin North Am 2004;51:939-59.

4. Rekam medik. Data angka kejadian penyakit pada pasien rawat inap periode Januari 2010-Desember 2013. Jakarta: Depkes RI; 2010.

5. Zardad Muhammad AA, Umar Hayat, Muhammad Salim Wazir, Rafiyatullah, Huma Waqas. Neonatal sepsis: causative bacteria and their resistance to antibiotics. J Ayub Med Coll Abbottabad 2010;224:33-5.

6. Marchant EA, Boyce GK, Sadarangani M, Lavoie PM. Neonatal sepsis due to coagulase-negative staphylococci.
Clin Dev Immunol 2013;2013:1-6.

7. Kuruvilla Pillai S, Mary J, Jana AK. Bacterial profile of sepsis in a neonatal unit in South India. Indian Pediatri 1997;35:851-8.

8. Del Vecchio L. Genetic polymorphisms in neonatal sepsis. Imunol Infect. 2006;2:31-7.

9. Abu-Maziad A, Schaa K, Bell EF, Dagle JM, Cooper M, Marazita ML, dkk. Role of polymorphic variants as genetic modulators of infection in neonatal sepsis. Pediatr Res. 2010;68:323-9.

10. Bertrand S, Filleron A, Mesnage R, Lotthe A, Didelot M, Burgel L. Staphylococcus aureus in a neonatal care center. Methicillin susceptible strains should be a main concern. Antimicrob Resist Infect Control 2014;3:1-9

11. Libert C, Dejager L, Pinheiro I. The X chromosome in immune functions: when a chromosome makes the difference. Nat Rev Immunol 2010;10:594-604.

12. Melville J, Moss T. The immune consequences of preterm birth. Front Neurosci 2013;7:79. doi: 10.3389/ fnins.2013.00079.

13. Tumangger H, Jamil K. Constribution of genes polymorphism to suspectibility and outcome of sepsis. Egypt J Med Hum Gen 2010;11:97-103.

14. Cardoso P, Oliveira A, Botoni F, Rezende I, Filho J, Cunha F. Interleukin-10 rs2227307 and CXCR2 rs1 126579 polymorphisms modulate the predisposition to septic shock. Mem Inst Oswaldo 2015;101:1-8. 